\title{
Erratum to: 'A Tragedy as Old as History': Medical Responses to Infertility and Artificial Insemination by Donor in 1950s Britain
}

\author{
Gayle Davis
}

Erratum to:

Davis G. (2017) 'A Tragedy as Old as History': Medical Responses to Infertility and Artificial Insemination by Donor in 1950s Britain, https:// doi.org/10.1057/978-1-137-52080-7_19, (c) The Author(s) 2017.

In: Davis G., Loughran T. (eds) The Palgrave Handbook of Infertility in History, (C) Palgrave Macmillan, London 2017.

This chapter has now been made available open access under a CC BY 4.0 license.

The updated online version of this chapter can be found at https://doi.org/10.1057/ 978-1-137-52080-7_19 